\title{
Methods of Design for Means of Egress: Towards a Quantitative Comparison of National Code Requirements
}

\author{
EZEL. KENDIK \\ COBAU Ltd. \\ Vienna, Austria
}

ABSTRACT

This paper provides a brief review of the modelling of people movement during the egress from buildings and discusses some of the questions raised by each type of modelling. Furthermore, it compares the predictions of a selected calculation method with regulatory requirements on means of escape in various countries.

\section{INTRODUCTION}

The increasing complexity of buildings concerning functions, size and configurations require a broader attention to the problems related to egress. Over the last two decades there has been considerable activity in modelling egress from buildings. According to the overall tendency in the technical literature the available models can be divided into two categories, viz. movement models and behaviour models. Although the former studies are generally concerned with the exiting flow of a buildings' occupants the design concepts show a somewhat dispersed variation.

The behavioural models as they have been developed, are essentially of two types, conceptual models which have attempted to include the observed, empirical and reported actions from collective interview or questionnaire studies, by Canter (1) and by Wood (2), and computer models for the simulation of the behaviour of the human individual in the fire incident. The conceptual models have attempted to include a theoretical design in the model which attempts to provide some understanding of decision making, and alternative choice processes of the individual involved with a fire incident situation. Most of the current models that have been developed of this type would probably be identified as describing the process of the participant in the fire incident as an information seeking and processing model. (after J. Bryan, ref.3)

The current models evolving from people movement may be classified as follows:

1. Flow models based on the carrying capacity of independent egress way components;

2. Flow models based on empirical studies of crowd movement; 
3. Computer simulation models; and

4. Network optimization models.

This presentation will primarily be concerned with the first and second items, since the former is still world-wide governing the regulatory approaches covering the exit geometry whilst the latter studies are supported by extensive research work conducted in real-world settings. But, before we turn to our primary concern two other models supported by U.S. National Bureau of Standards should be acknowledged.

\section{BEIRES II: A BEHAVIOUR BASED SIMULATION OF EMERGENCY EGRESS} DURING FIRES

This model by F.Stahl (4), (5) is a dynamic stochastic computer simulation of emergency egress behaviour of building occupants during fires. It is a modified and expanded version of BFIRES I (6), which was originally developed for the application to the health care occupancy. The model is not calibrated against real-world events, but a sensitivity analys is of the model proved that BFIRES outcomes are sensitive to (a) floor plan confuguration, (b) occupants' spatial locations at the onset of the emergency event, (c) the existence of any impairments to occupants' mobility, (d) occupants' familiarity with the building layout, and (e) permissible levels of occupant density.

The most interesting finding of this sensitivity analysis is that, when the individuals vary on the basis of occupant parameters (mobility impairment and and knowledge of safe exit location) the effects of variation in enviromental parameters (occupant density and spatial subdivision) disappear. As a result of this stahl suggests that occupants unfamiliar with the building's physical layout will not be helped by designs providing shorter and more direct egress routes. This challenges the traditional design conventions.

The concept and structure of the model is described by Stahl as follows:

BFIRES conceptualizes a building fire event as a chain of discrete "time frames" and for each such frame, it generates a behavioural response for every occupant in accordance with their perceptions of a constantly changing environment. When preparing a behavioural response at $\mathrm{T} i$, a simulated occupant gathers informationwhich describes the state of the environment at this point in time. Next, the occupant interprets this information by comparing current with previous distances between the occupant, the fire threat, and the exit goal and by comparing "knowledge" about threat and goal locations possessed by the occupant, with amounts possessed by other nearby simulated persons. Current locations of physical barriers and of other occupants are also taken into account... The selection of a behavioural response (i.e. the decision to move in a particular direction) results from the comparison of available move alternatives with the occupant's current move criteria.

Here, the choise of exits and the selection of alternative moves appear to be critical. In the first report of BFIRES (6) it is suggested that, as the literature in human behaviour in fires 
(or fire drills) provide no guidance, that, if $60 \%$ (or more) of the occupants inhabiting a space favor a particular exit from the space, they will "convince" the remaining occupants of the quality of their opinion, and all the occupants will seek the exit. This option is not necessarily consistent with the human nature. The opposite choice might be that the majority follows one person.

About the criteria of selecting alternative moves, Stahl writes as follows:

To date, it has not been possible to calibrate computed values of the probability that an occupant will, during a given time frame select some move alternative, against data from actual fire situations. This is because no data on human behaviour during fires exist to describe emergency decision making processes at so fine a. level of detail. Considerable research will be necessary to understand the mechanism by which people under emergency conditions perceive alternative courses of action, relate such alternatives to broader egress strategies and then select appropriate actions.

In spite of the limitation, that the model deals with maximum 20 persons in a simulation, it appears to be the only computer program attempting to simulate the individuals' information processing, decision making and responses to a migrating fire threat, like smoke and toxic agents.

\section{EVACNET: A COMPUTERIZED NETWORK FLOW OPTIMIZATION MODEL (8), (9)}

This model, developed by R.L.Francis et al. determines an evacuation routing of the people so as to minimize the time to evacuate the building. Network models are not behavioural in nature. Rather they demonstrate a course of action which, if taken could lead to an evacuation of a building in an "appropriate" manner. The model represents the building's evacuation pattern as it changes over time, in discrete time periods. The model is able to answer several "what if" questions like "how should the building be evacuated if the fire breaks out on the tenth floor or what if more stairwells are added. (9)

The static network model is basically a transshipment model, where origins represent work centers, transshipment nodes represent portions of the building and destinations represent the building exits. The static capacity of the node gives the maximum number of persons simultaneously allowed to stay in this space. The nodes are connected by arcs, of which the dynamic capacities are upper bounds on flow rates. Based on J. Pauls"'effective width" model, the model assumes constant flow rates in stairwells for a given number of occupants in the building. This assumption that the stairwell flow rates are independent of stairwell usage, appears to be a limitation of the network flow model, since its approach is somewhat contradictory to the effective width model. Pauls' equation predicts the mean flow rate for the assessment of the overall evacuation performance, while the network model looks at the evacuation pattern every ten seconds.

The network flow optimization model is able to deal with large number of people as well as with complex buildings. 


\section{FLOW MODELS BASED ON THE CARRYING CAPACITY OF INDEPENDENT EGRESS}

WAY COMPONENTS

The historical development of carrying capacity investigations has been already broadly reviewed by F.Stahl and J.Archea (10), (11) and J.Pauls (12), (13), in several publications. Hence, this presentation will be confined to the discussion of the calculation methods based on these investigations.

An early NFPA document recommended as a guideline for stair design an average flow rate of 45 persons/minute/22" width unit. (after ref.10) In 1935, in a publication of the U.S. National Bureau of Standards, test results about measurements of flow rates through doors corridors and on stairs under non-emergency conditions were presented. There,for different types of occupancy the measured maximum flow rates varied between 23 and 60 persons/min/ unit stair width, and 21 and 58 persons/min/unit door or ramp width. (14) Up to date, the NFPA Life Safety Code 101 (15) maintained the unit exit width concept together with the travel distances and the occupant load criteria. But, for some reason the time component is left out in the present code.

In the U.K. the first national guidance for places of public entertainment was produced in 1934 (16); the recommendations in which had been "based not only on experience gained in the U.K., but on a study of disasters which have happened abroad and of the steps taken by the authorities of forein countries". (17) In this document the following formulae for the determination of total width of exits required from each portion of a building were provided reflecting the concept of the unit exit width:

$A=Z$ (Floor area in $s q f) / E$ B $C \quad D$

$A$ is the number of the units of exit width required;

$B$ is a constant as to the construction type of building;

$\mathrm{C}$ is a constant for the arrangement and protection of the stairs;

$D$ is a constant for the exposure hazard;

$E$ is a factor dependent apon height of floor above or below ground level;

$\mathrm{Z}$ is the class of user of the building (closely seated audience etc.).

$N=A / 4+1$

$\mathrm{N}$ is the number of exits required. In this document it was also stated, that about 40 persons per minute per unit exit width downstairs or through exits is an appropriate figure in connection with these formulae.

In fact the width of exits had been discussed ten years previously in a document for the fire protection in factories, (7), where it was reported that tests in the U.K. and in America had found that on average 40 persons per foot of width per minute was possible for "young and active lads" moving "through door-ways with which they were aquainted", but that figure would have to be reduced very conciderably for theatre audiences, it was considered that in factories a figure of 20 persons per foot of width per minute was quite safe under conditions ruling in a factory. (after ref.17) 
40 persons/min/unit of exit width is also recommended in the Post-War Building Studies No.29. (18). In this report another ca1culation method is suggested. (Appendix II) The width of staircases in the current GLC Code of Practice (19), as well as in the BS 5588 Part 3 (20) are computed by this method (21), which calculates the total population a staircase can accomodate based on the following assumptions:

1. Rate of flow through an exit is 40 persons per unit width per minute;

2. Each storey of the building is evacuated on to the stairs in not more than $2.5 \mathrm{~min}$. (This average clearance time was proposed after an evacuation experience during a fire in the Empire Palace Theatre in Edinburgh in 1911; (18)

3. There is the same number of people on each storey;

4. Evacuation occurs simultaneously and uniformly from each floor;

5. In moving at a rate of 40 persons/unit width/min, a staircase can accomodate one person per unit width on alternate stair treads and 1 person per each $3 \mathrm{sq}$. ft. of landing space;

6. The storey height is $10 \mathrm{ft}$;

7. The exits from the floors on the stairs are the same width as the stairs; and

8. People leaving the upper floors are not obstructed at the ground floor exit by persons leaving the ground floor.

$\mathrm{P}=$ (staircase capacity)(nu.of upper storeys) $+\left(t_{e}-t_{s}\right) r \mathrm{~W}$

$t_{e}$ is the maximum permissible exit time from any one floor onto the staircase (taken as 2.5 min.);

$t_{s}$ is the time taken for a person to traverse a storey height of stairs at the standard rate of flow (predicted as $0.4 \mathrm{~min}$ );

$r$ is the standard rate of flow (taken as 40 persons/unit/min); and $w$ is the width of staircase in units.

The staircase capacity is predicted after point 5 of the above as sumptions .

This method of calculation predicts with increasing number of storeys fewer persons per floor.

K.Togawa in Japan (1955), whose studies are hardly accessible, was apparently the first researcher who attempted to model mathematically the people movement through doorways, on passageways, ramps and stairs. (after Pauls,(13), Stahl and Archea,(10), and Kobayashi,(22) ) He provided the following equation:

$v=v_{0} D^{-0.8}$

$\mathrm{v}$ is the flow velocity;

$V_{0}$ is a constant velocity $(1.3 \mathrm{~m} / \mathrm{sec}$, which is apparently

the velocity under free flow conditions); and

$D$ is the density in persons per sq $\mathrm{m}$.

Hence, the flow rate $N$ is given by

$\mathrm{N}=\mathrm{V}_{\mathrm{O}} \mathrm{D}^{0.2}$

This $\mathrm{N}$ is the same as the specific flow "q" referred to later. 
Based on the data from the investigations by Togawa and the London Transport Board (23) S.J. Melinek and S.Booth (24) analysed the flow movement in buildings and provided the following formulae:

1. The maximum population $M$ which can be evacuated to a staircase, assuming a permitted evacuation time of $2.5 \mathrm{~min}$, is given by

$M=200 b+\left(18 b+14 b^{2}\right)(n-1)$

$\mathrm{b}$ is the staircase width in $\mathrm{m}$; and

$\mathrm{n}$ is the number of storeys served by the staircase.

This equation predicts higher number of persons than the method presented in the Post-War Building Studies No.29.

If the population $Q$ and the staircase width b are the same for each floor then the minimum evacuation time is the larger of $\mathrm{T}_{1}$ and $T_{n}$ where

$T_{1}=n Q /\left(N^{\prime} b\right)+t_{s}$
$T_{n}=Q /\left(N^{\prime} b\right)+n t_{s}$

$\mathrm{T}_{1}$ corresponds to congestion on all floors and $\mathrm{T}_{\mathrm{n}}$ to no congestion. Melinek and Booth suggested as typical values of $N^{\prime}$ and $t_{s}$ 1.1 persons $/ \mathrm{sec} / \mathrm{min}$ and $16 \mathrm{sec}$. Compared with evacuation tests in multi-storey buildings the method predicted in most cases evacuation times which are too low.

A further application of the unit width concept has been the mathematical model of W.Müller in East Germany. (25), (26), (27). Assuming a flow rate of 30 persons/min $/ 0.6 \mathrm{~m}$ stair width Müller provided the following equation for the assessment of the total evacuation time in multi-storey buildings:

$t=\left(3 h_{G} / v\right)+\left(P /\left(b f_{O} / 0.6\right)\right)$

$h_{G}$ is the floor height;

$\mathrm{P}$ is the number of persons in the building;

$\mathrm{b}$ is the stair width in $\mathrm{m}$;

$\mathrm{v}$ is the flow velocity down stairs of $0.3 \mathrm{~m} / \mathrm{sec}$; and

$f_{0}$ is the flow rate/unit stair width of $0.6 \mathrm{~m}$.

The minimum evacuation time via the staircase is

$\mathrm{t}=10 \mathrm{~h}_{\mathrm{G}}+15 \mathrm{~h}_{\mathrm{G}} \mathrm{n}$

Miller suggested the limitation of building height rather than to widen the staircases.

\section{FLOW MODELS BASED ON EMPIRTCAL STUDIES OF CROWD MOVEMENT}

During the last decade Jake Pauls (Canada) developed the "effective width" model. This model is based upon his extensive empirical studies of crowd movement on stairs as well as the data about the mean egress flow as a function of stair width. In this context he conducted several evacuation drills in high-rise office build- 
ings and observed normal crowd movement in large public-assembly buildings. The model describes the following phenomena (13), (29), (30):

1. The usable portion of a stair width, i.e. the effective width of a stair begins approximately $150 \mathrm{~mm}$ distance from a boundary wall or $88 \mathrm{~mm}$ distance from the centerline of a graspable handrail. (edge effect)

2. The relation between mean evacuation flow and stair width is a linear function and not a step function as assumed in traditional models based on lanes of movement and units of exit width. The evacuation flow is directly proportional to the effective width of a stair.

3. Mean evacuation flow is influenced in a nonlinear fashion by the total population per effective width of a stair.

Pauls provides the following equation for the evacuation flow in persons per metre of effective stair width:

$f=0.206 \mathrm{p}^{0.27}$

$p$ is the evacuation population per metre of effective staix width. The total evacuation time is given by

$t=0.68+0.081 \mathrm{p}^{0.73}$

This calculation method has been recently accepted for an appendix to the NFPA Life Safety Code, 1985 edition.

Now, we turn to another flow model developed by Predtechenskii and Milinski in the Soviet Union. (31) This method is a deterministic flow model, which predicts the movement of an egressing population on a horizontal or a sloping escape route instantaneously in terms of its density and velocity.

Predtechenskii and Milinski measured the flow density and velocity in different types of buildings nearly 3600 times under normal environmental conditions. Their observations indicated, that the flow velocity shows a wide variation, especially in the range of lower densities. The following equation relating the ratio between the sum of the persons ' perpendicular projected areas ( $P f$ ) and the available floor area for the flow, estimates the flow density homogeneously over the area of an escape route:

$D=P E / b 1$

$P$ is the number of persons in the flow;

$f$ is the perpendicular projected area of a person;

$\mathrm{b}$ is the flow width, which is identical with the width of the escape route; and

1 is the flow length.

Note $\mathrm{D}$ has no dimensions.

The egress populatian passing a definite cross section on an escape route of the width of $b$, is referred to as flow capacity.

$\mathrm{Q}=\mathrm{D} \mathrm{vb} \quad \mathrm{m}^{2} \mathrm{~min}^{-1}$ 
Here, $\mathrm{v}$ is the flow velocity. Another flow parameter is the flow capacity per metre of the escape route width, which is defined as the specific flow:

$\mathrm{q}=\mathrm{DV} \quad \mathrm{m} \mathrm{min}^{-1}$

The efficiency of an evacuation depends on the continuity of the flow between three restrictions, viz. the horizontal passages, doors and stairs. Hence, the main condition for the free flow is the equivalence of flow capacities on the successive parts of the escape route:

$Q_{i}=Q_{i+1}$

If the value of the specific flow q exceeds the maximum, the flow density increases according Predtechenskii and Milinski to a maximum value, which in effect leads to queuing at the boundary to the route $i+1$. At this stage, the flow consists of two parts, viz. of a group of persons with the maximum flow concentration who has already arrived at the critical section of the escape route, and the rest of the evacuees approaching by a higher velocity and a density less than $D_{\max }$. In this case the rate of congestion is given by the following equation:

$v_{\text {STAU }}^{\prime \prime}=\left(q_{\text {Dmax }} b_{i+1} / b_{i}-q_{i}\right) /\left(D_{\max }-D_{i}\right)$

$\mathrm{q}_{\text {Dmax }}$ is the specific flow at the maximum density;

$b_{i+1}$ is the width of the congested flow;

$b_{i}$ is the initial width of the flow;

$\mathrm{q}_{i} \quad$ is the initial value of the specific flow; and

$D_{i} \quad$ is the initial flow density.

After the last person moving at the higher velocity reaches the end of the queue, the congestion diminishes at

$\mathrm{v}_{\mathrm{STAU}}=\mathrm{v}_{\operatorname{Dmax}} \mathrm{b}_{\mathrm{i}+1} / \mathrm{b}_{\mathrm{i}}$

where $v_{\text {Dmax }}$ is the flow velocity at the maximum density.

This calculation method has been mainly applied by Predtechenskii and Milinski to the evacuation of auditoriums and halls.

A MODEL FOR THE EVACUATION OF MULTI-STOREY BUILDINGS VIA STAIRCASES

Kendik (32)-(35) developed an egress model based on the above work. This has been calibrated against the data from the evacuation tests carried out by the Forschungsstelle für Brandschutztechnik at the University of Karlsruhe. (36) If the following simplifications

1. The length 1 of the partial flow built up by the occupants of each floor (defined between the first and the last persons of the flow) is assumed to be equivalent to the greatest travel distance along the corridor;

2. The number of persons as well as the escape route configurations are identical on each storey; and

3. Each partial flow attempts to evacuate simultaneously, and enters the staircase at the same instant. 
are introduced into the general mode the flow movement via staircases shows some regularities:

1. If the evacuation time on the corridor of each floor, $t_{F}$, is less than the evacuation time on the stairs per floor, $t_{\text {Tr }}$, then the partial flows from each floor can leave the building without interaction. In this case, the total evacuation time is given by the following equation:

$t_{\text {Ges }}=t_{F}+n t_{T R}$

$t_{F}$ is the evacuation time on the corridor of each floor;

$\mathrm{n}^{\mathrm{F}} \quad$ is the number of the upper floors; and

$t_{T R}$ is the evacuation time on the stairs per floor.

2. If the evacuation time on the corridor of each floor, $t_{F}$ exceeds the evacuation time on the stairs per floor, $t_{\mathrm{rp}}$, then the partial flows from each floor encounter the rest of the evacuees entering the staircase on the landing of the storey below. Even though this event causes the increase of density on the stairs, the capacity of the main flow remains under the maximum value, $Q_{\max }$, which indicates, that the stair width is still appropriate to take up the merged flow, i.e. if

$t_{\mathrm{F}}>t_{\mathrm{TR}}$, and

$\mathrm{q}_{\mathrm{TR} ; \mathrm{n}-1}=\left(\mathrm{Q}_{\mathrm{T} ; \mathrm{n}-1}+\mathrm{Q}_{\mathrm{TR}}\right) / \mathrm{b}_{\mathrm{TR}}<\mathrm{q}_{\mathrm{TR} ; \max }$

where

GTR;n-1 is the value of the specific flow on the stairs after

the merging process,

$\mathrm{Q}_{\mathrm{T} ; \mathrm{n}-1}$ is the flow capacity through the door to the stairca-

$Q_{T R}$ is the initial flow capacity on the stairs, and

$\mathrm{q}_{\mathrm{TR}}$;max is the maximum flow capacity on the stairs,

then the total evacuation time is given by

$\mathrm{t}_{\mathrm{GeS}}=\mathrm{t}_{\mathrm{F}}+\mathrm{n} \mathrm{t}_{\mathrm{TR}}+\mathrm{m} d \mathrm{t}$

where the last term of the equation relates the delay time of the last person from the top floor. The factor $m$ is the number of patterns of higher density, which reduces during the course of the evacuation process. $m$ can be assessed by an iteration.

3. If the value of the specific flow on the stairs exceeds the maximum during the merging of the partial flows at the storey $(n-1)$ congestion occurs on stairs as well as at the entry to the staircase. In this case, the total evacuation time of a multi-storey building is determined by the following equation:

$t_{\text {Ges }}=t_{T R ; S T A U}+(n-1)\left(1_{T R} / v_{T R} ; n-1\right)+(n-2) d t$

$t_{\text {TR; }}$ STAU is the length of time required for the flow to leave

the floor level $(n-1)$;

$I_{T R} \quad$ is the travel distance on the stairs between adjoining storeys;

$\mathrm{V}_{\mathrm{TR}} ; \mathrm{n}-1$ is the velocity of the flow emanating from the con- 
The total evacuation time $t_{G e s}$ is influenced in a non-linear fashion by the projected area factor (or the density increase).

The above results follow from the three simple situations described earlier. Recently, Kendik prepared a computer program in Basic language for a HP 150 personel computer based on the described egress model. The program enables the user to change the dimensions of the building's means of egress and the occupant load easily and work out the influence of the variation on the complete circulation system.

Kendik's egress model addresses the time sequence from when people start to evacuate the floors until they finally reach the outside or an approved refuge area in the building within the available safe egress time. Hence, it doesn't consider the time prior to their becoming aware of the fire nor their decisionmaking processes. But, it can cope with the problem of the potential congestion on stairs and through exits including the interdependencies between adjacent egress way elements, which appear to be a major problem, especially in case of high population densities.

The method differs from other egress models mainly in its flexibility in predicting the variation of the physical flow parameters during the course of the movement. In this it does not as sign fixed values to the flow density or velocity for each individual or seperate groups but considers them to be a single group of a certain mean density on each section of the escape route.

\section{A QUANTITATIVE COMPARISON OF NATIONAL CODE REQUIREMENTS ON MEANS OF EGRESS}

As already mentioned elsewhere in this paper the regulatory requirements covering the exit geometry in several countries involve explicitly or implicitly the unit exit width concept accompanied by other criteria such as travel distances, occupant load, total number of occupancy, dead ends or maximum floor area. At the present moment only the building codes in Soviet Union (37) require a mathematical proof for the width of escape routes in buildings where the travel distance to one exit is more than 25 metres and the occupancy per floor using an exit exceeds 50 persons. The building codes in the Soviet Union as well as the new building codes in East Germany (38) use the flow model of Predtechenskii and Milinski under free flow conditions.

The building codes selected for inclusion in this study have been the Greater London Council Code of Practice (19), NFPA 101 New Business Occupancies (15), the German Building Codes for High-rise Buildings and Assembly Occupancies, the Japanese Design Guideline for Building Fire Safety (from ref.22), the Russian Building Codes (37) and the Building Codes for Vienna (41). The requirements in these codes have been compered with the predictions of the egress model developed by Kendik based on the data after Predtechenskii. 
An example from an earlier paper (42) illustrates how the calculation method have been employed for this purpose:

According to the National Fire Codes (101-316, Chapter 26) the capacity of stairs, outside stairs and smokeproof towers for new business occupancies has to be one unit for 60 persons. (120 persons per $1.12 \mathrm{~m}$ ). Furthermore, it is written that "for purposes of determining required exits, the occupant load of business buildings or parts of buildings used for business purposes shall be no less than one person per $100 \mathrm{sq}$ ft (9.29 $\mathrm{sqm}$ (sic)) of gross floor area and the travel distance to exits, measured in accordance with Section $5-6$, shall be no more than $200 \mathrm{ft}(60.96 \mathrm{~m}$ (sic)). Not less than two exits shall be accessible from every part of every floor". After Section 5-6.1 the maximum travel distance in any occupied space to at least one exit, shall not exceed the 1 imits specified for individual occupancies, in this case $200 \mathrm{ft}$.

These provisions might permit one to design a multi-storey office building of roughly $2400 \mathrm{sq}$ m per floor with two remote exits each with a width of two units and circa 240 occupants perfloor.

Assuming the stairs to be used at capacity levels and the widths of all exits (doors and stairs) as well as the escape routes leading to the staircases to be identical, the described flow model predicts for new business occupancies, that the last person from a floor enters the staircase after $2.15 \mathrm{~m}$ in under congested flow conditions. The number of persons moving in the overcrowded flow would be 37. This means that a protected lobby of at least $10.5 \mathrm{~m} 2$ (37 $\mathrm{x}$ $0.28 \mathrm{~m} 2$ ) or two staircases with a width of $1.20 \mathrm{~m}$ were necessary to accomodate 120 persons per floor. In the latter case the exiting time of the last person from a storey would be $1 \mathrm{~min}$. Without interaction of flows a staircase with a width of $1.12 \mathrm{~m}$ (2 units) would be able to accomodate 35 persons per floor. In this case the egress time from a floor would be about $0.4 \mathrm{~min}$.

Time is an important criterion for the flexible and cost effective design of escape routes. Figure 1 illustrates the comparison of the calculated stair capacities with the requirements of various building codes on means of escape. Here, the calculated number of persons per floor are predicted under the assumption that the egress time from a floor will be $1 \mathrm{~min}$. The horizontal axis gives the number of persons a staircase with a certain width would accommodate required in various codes, while the vertical axis are the predicted figures. It is interesting to notice, that most of the investigated code provisions relating stair capacity lie under the reference line. This might indicate, that the requirements of the existing codes imply floor evacuation times greater than $1 \mathrm{~min}$. (In one case up to 5 min, ref.19).

The correlation between the reference line and required number of persons in regulations would change in accordance with the egress time from a floor. Namely, if the available time for all occupants to evacuate one floor is expected to be about $2 \mathrm{~min}$ for the above example the required stair capacity would suffice to accomodate the given occupancy. If the available evacuation time is expected to be $3 \mathrm{~min}$ the required stairs widths are likely overestimated for the given occupancy. 


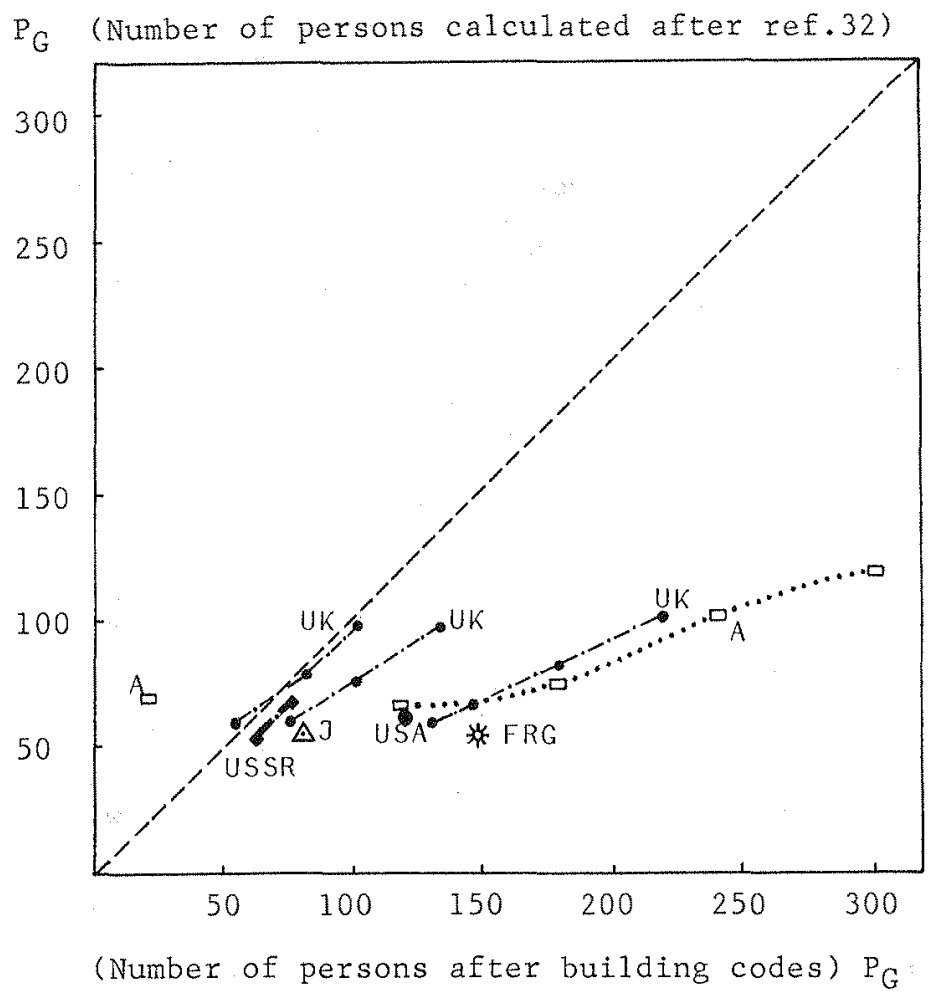

FIGURE 1. Graphical representation of the calculated stair capacity against requirements of building codes on means of escape.

\section{CONCLUSIONS}

Recently, there has been considerable activity in modelling egress from buildings. The numerous methods available are basicly either behaviour or movement models. All of them appear to make several assumptions, partly to overcome the gaps in the technical 1iterature, which makes their validation against real-world events or fire drills necessary. In fact, only a few of these models are calibrated in this manner and able to provide quantitative results.

The physical structure of a building is apparently an elementary determinant of its occupants' behavioural responses and actions to the changing environmental conditions in terms of time. The time needed to reach a place of safety inside or outside the building might strech from the time people need to escape by theirown unaided efforts, as very often stated or implied in most of the national fire codes, until the time handicapped as well as non-handicapped persons need to be rescued. Hence, the critical nature of time requires an analysis that enables the designers to select an appropriate egress system and to estimate the escape facilities by exploiting performance-oriented calculation methods. 
This paper also provided a quantitative comparison of the predictions of a selected flow model with the requirements of various codes that do not employ such methods but appear to be based on experience and judgment. In this way time should be regarded as a design component for means of escape in order to improve cost effectiveness and design flexibility.

\section{REFERENCES}

1. Canter, D.: Human Behaviour in Fires. Guilford, University of Surrey, Department of Psychology, U.K. 1978.

2. Wood, P.G.: The Behaviour of People in Fires. BRE Fire Research Station, Fire Research Note 953, UK, 1972.

3. Bryan J.L.: Implications for Codes and Behaviour Models from the Analysis of Behaviour Response Patterns in Fire Situations as Selected from the Project People and Project People II Study Programs. NBS-GCR-83-425, sponsered by National Bureau of $\frac{\text { Stan- }}{\text { Bards. }}$ dards, Department of Commerce, Washington, March 1983.

4. Stah1, F.: BELRES/Version 2: Documentation of Program Modifications. NBSIR 80-1982, U.S.Department of Commerce NBS Center for Building Technology, Washinton D.C., March 1980.

5. Stahl, F.: BEIRES II: A Behaviour Based Computer Simulation of Emergency Egress During Fires. Fire Technology, Feb.1982, p. $\overline{\text {. }}$.

6. Stahl, F.: Final Report on the "BFIRES/Version 1" Computer Simulation of Emergency Egress Behaviour During Fires: Calibration and Analysis. NBSIR 79-1713, U.S.Department of Commerce, NBS, Center for Building Technology, Washington D.C. , March 1979.

7. Home Office: Fire Protection in Factories. Safety Pamplet No. 13. London. HMSO. 1928.

8. Francis, R.L. and Saunders P.B.: EVACNET: Prototype Network Optimization Models for Building Evacuation. NBSIR 79-1738. Operations Research Division, Center for Applied Mathematics, U.S.Department of Commerce, NBS, Washington D.C. 1979.

9. Chalmet, L.G., Francis, R.L., Saunders, P.B.: Network Models For Building Evacuation. Fire Technology, Feb. 1982, p.90.

10. Stahl, F.I. Archea, J. : An Assessment of the Technical Literature on Emergency Egress from Buildings. NBSTR 77-1313, Center for Building Technology, National Bureau of standards, U.S. Dept. of Commerce, Washington, D.C. 1977.

11. Stah1, F.: Time Based Capabilities of Occupants to Escape Fires in Public Buildings: A Review of Code Provisions and Technical Literature. NBSIR $82-2480$. U.S.Dep. of Commerce, $\overline{\text { NBS Center }}$ for Building Technology, Washington D.C., 1982.

12. Pauls, J.L. : "Building Evacuation: Research Findings and Recommandations. In Fires and Human Behaviour," ed. D. Canter, New York, John Wiley and Sons (1980), p. 251. 
13. Pauls, J.: Nevelopment of Knowledge about Means of Egress. Fire Technology, Volume 20 , Number 2, May 1984.

14. National Bureau of Standards: Design and Construction of Building Exits. US Dep. of Commerce, NBS M151, Washington D.C.,1935.

15. National Fire Codes, Volume 9, Code for Safety to Life from Fire in Buildings and Structures, NFPA 101. 1982.

16. Home Office: Manual of Safety Requirements in Theatres and Other Places of Public Entertainment. London, HMSO, 1935.

17. Read, R.: Means of Escape in Case of Fire: The Development of Legislation and Standards in Great Britain. To be published.

18. Post-War Building Studies No.29, Fire Grading of Buildings, Part III: Personal Safety. London, HMSO 1952.

19. GLC Code of Practice, Means of Escape in Case of Fire. UK,1974.

20. British Standard BS 5588: Fire Precautions in the Design and Construction of Buildings, Part 3. Code of Practice for office Buildings. British Standards Institution, 1983, p.20.

21. Tidey, J.: Greater London Council; private communication. 1983.

22. Kobayashi, M. : Design Standards of Means of Egress in Japan. International Seminar on Life Safety and Egress at the University of Maryland, MD, U.S.A. November, 1981.

23. London Transport Board: II. Report of the Operational Research Team on the Capacity of Footways. London Transport Board Research Report, UK, 1958.

24. Melinek, S.J., Booth, S.: An Analysis of Evacuation Times and the Movement of Crowds in Buildings. BRE, Fire Research Station CP 96775,1975 .

25. Müller, W.L. : Die Beurteilung von Treppen als Rückzugsweg in mehrgeschossigen Gebäuden. Unser Brandschutz $16,(1966), \sqrt{\mathrm{Nr}} .8$, wissenschaftlich-techn. Beilage Nr.3 p.65; Unser Brandschutz 16, (1966), Nr.11, wissenschaftlich-techn. Beilage Nr.4, p.93.

26. Müller, W.L. : Die Überschneidung der Verkehrsströme bei dem Berechnen der Răumungszeit von Gebäuden. Unser Brandschutz 18 (1968) Nr.11, wissenschaftlich-technische Beilage Nr.4, p.87.

27. Müller, W.L.: Die Darstellung des zeitlichen Ablaufs bei dem Räumen eines Gebäudes. Unser Brandschutz 19 (1969) Nr.1, Wissenschaftlich-technische Beilage Nr.4, p.6.

28. Pauls, J. and Jonas, B. : Building Evacuation: Research Methods and Case Studies. In Canter (ed.) Fires and Human Behaviour. Wiley a. Sons Ltd., Chapter 13, 1980.

29. Pauls, J.: Effective-width Mode1 for Crowd Evacuation. VFDB,6th International Fire Protection Seminar, Karlsruhe, FRG, 1982. 
30. Pauls, J.: The Movement of People in Buildings and Design Solutions for Means of Egress.Fire Technology, Vol.20,Nr.1,1984, p.27.

31. Predtechenskii, W.M., Milinski, A.I.: Planning of Foot Traffic Flow in Buildings. Published for National Bureau of Standards by Amerind Publishing Co. Pvt. Ltd., New Delhi, 1978.

32. Kendik, E.: Die Berechnung der Räumungszeit in Abhängigkeit dex Projektionsfläche bei der Evakuierung der Verwaltungshochhäuser über Treppenrëume. VFD $\bar{B}$, 6 th Internationa 1 Fire Protection Seminar, Karlsruhe, FRG; 1982.

33. Kendik, E.: Determination of the Evacuation Time Pertinent to the Projected Area Factor in the Event of Total Evacuation of High-Rise office Buildings via Staircases. Fire Safety Journal, 5(1983) p.2 23 .

34. Kendik, E.: Die Berechnung der Personenströme als Grundlage für die Bemessung von Gehwegen in Gebäuden und um Gebäude. Techn i

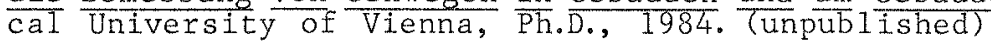

35. Kendik, E.: Assessment of Escape Routes in Buildings- Discussion of a Design Method for Calculating Pedestrian Movement. Paper presented at the 1984 Annual Conference on Fire Research held at the Center for Eire Research, National Bureau of Standards, Gaithersburg, Maryland, Oct.1984, unpublished.

36. Seeger, P. John, R. : Untersuchung der Räumungsabläufe in Gebäuden als Grundlage für die Ausbildung von Rettungswegen, Teil III: Reale Räumungsversuche. Stuttgart, Informationszentrum für

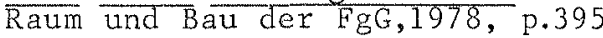

37. SNIP II-82-80, Baunormen und Bauvorschriften Teil II: ProjekEierungsnormen Blatt 2: Brandschutznormen für die Projektierung von Gebäuden und baulichen Anlagen. Staatliches Komitee für Bauwesen (GOSSTROI) der UdSSR. Verlag für Bauwesen, Moskau, 1980.

38. Technischer Materialien zur Standardisierung (TMS)-Bautechnischer Brandschutz, Evakuierung von Personen aus Bauwerken. Brandschutz- Explosionsschutz, Aus Forschung und Praxis 3. Staatsverlag der DDR, Berlin, 1980. p.144.

39. Muster für Richtlinien über die bauaufsichtliche Behandlung von Hochhäusern. Fachkommission Bauaufsicht der ARGEBAU, FRG; 1979.

40. Versammlungsstättenverordnung-VStättVO Baden-Württemberg vom 12. Februar 1982. Vorbeugender Brandschutz, Hg.VFDB, 5.3 Batiten besonderer Art- Teil IT: Versammlungstätten, Wiesbaden, 1982.

41. Landesgesetzblatt für Wien, Jahrgang 1976, 18.Gesetz: Bauordnung für Wien, $\$$ 106: Stiegen, Gänge und sonstige Verbindungswege. Vienna, $197 \overline{6}$

42. Kendik, E.: Assessment of Escape Routes in Buildings and a DeDesign Method for Calculating Pedestrian Movement. Presented at SFPE'S 35 th Anniversary Engineering Seminar, Chicago, May 1985. 
